\title{
Г. Канай
}

Назарбаев университеті Жоғары білім беру мектебі, Қазақстан, Нұр-Сұлтан қ. e-mail: gkanayeva@nu.edu.kz

\section{ҰСТАЗ КӘСІБИАІГІ МЕН КӨШБАСШЫАЫҒЫ: ҚАЗАҚСТАННЫҢ ТӨРТ МЕКТЕБІНАЕ ҰСТАЗ КӨШБАСШЫАЫҒЫН ААМЫТУ}

\begin{abstract}
Ic-әрекеттегі зерттеу әдіснамасына (Kemmis et al., 2014) негізделген атаммыш зерттеуде Қазақстанның төрт мектебінде ұстаз көшбасшылығын дамытуға бағытталған бағдарламаны енгізу арқылы пайда болған білім ұсынылады. Аауазымға тәуелсіз ұстаз көшбасшылығы (Frost et al., 2000) концептісіне негізделген бағдарламаны енгізу арқылы аталмыш зерттеу 'төменнен төбеге', яғни мектептен орталыққа қарай жүретін инновация мен өзгерісті енгізуді, мектеп ішінен көшбасшылықты және үздіксіз кәсіби даму стратегиясын іске асыруды көздеді. Тоғыз айға созылған ұстаз көшбасшылығын дамыту бағдарламасы "Кәсіби білім алу мен ынтымақтасуға бағытталған ұстаз көшбасшылығы” деп аталды. Бағдарлама аясында арнайы стратегиялар енгізіліп, мектеп ішінде ұстаздарға өз бетімен сынып пен дамыту мен өзгеріс енгізуге бағытталған жобаларға жетекшілік етуге жағдай жаса^ды. Ұстаздардың көшбасшылық жобалары сыныптың және жалпы мектептің дамуына ықпалдарын тигізді. Зерттеу қорытындылары ұстаз көшбасшылығының дамуы үшін ұстаздардың кәсіби рөлдерінің кеңейтілу керек екендігін және мектептің үздіксіз білім алатын ұйымға айналу керек екендігін көрсетті. Яғни, орта білім беру саласындағы реформалардың сәтті іске асуы үшін мектеп ішіндегі көшбасшылық әлеуетті дамытуға бағытталған жүйе мен ұстаздарға арнайы қолдау көрсетілуі қажет екендігі белгілі болды.

Түйін сөздер: ұстаз көшбасшылығын дамыту, мектеп көшбасшылығы, ұстаздардың кәсіби білім алуы, орта білім берудегі реформа, іс-әрекеттегі зерттеу.

\section{G. Qanay \\ Nazarbayev University Graduate School of Education, Kazakhstan, Nur-Sultan e-mail: gkanayeva@nu.edu.kz \\ Teacher Professionalism and Leadership: Developing Teacher Leadership in Four Schools in Kazakhstan}

This paper provides an account of an action-based study (Kemmis et al., 2014), which was conducted with the purpose to develop teacher leadership in four schools in Kazakhstan. By drawing on a nonpositional approach to teacher leadership (Frost et al., 2000), this study sought bottom-up approaches to educational reform, school leadership and professional development in schools in Kazakhstan. The nine-month intervention programme, which was called the Teacher Leadership for Learning and Collaboration, introduced strategies and created conditions for teachers to lead educational improvement at classroom, school and system level. Teachers' leadership projects had an impact on classroom and whole-school practices. The outcomes of this study indicate that there is a need for revisiting teachers' professional roles in schools and transforming schools into a learning organisation. As such, educational reform and improvement requires building local capacity, which may involve creating conditions for leadership development and teacher empowerment within schools.

Key words: teacher leadership development, school leadership, professional learning, school reform, action-based research.

\section{Г. Канай}

Высшая школа образования, Назарбаев университет, Казахстан, г. Нур-Султан e-mail: gkanayeva@nu.edu.kz

Профессионализм и кидерство учителей: развитие кидерства учителей в четырёх школах Казахстана

В статье представлены результаты исследования в действии (Kemmis et al., 2014), которое проводилось с целью развития лидерства учителей в четырех школах Казахстана. Основываясь на непозиционном подходе к милерству учителей (Frost et al., 2000), это исследование было 
направлено на поиск подходов реформы «снизу вверх» путем создания условий Аля развития ^идерства и профессионального развития учителей внутри школ Казахстана. Программа, которая Алилась около девяти месяцев, была названа "Аидерство учителей Аля обучения и сотрудничества». В рамках программы была внедрена стратегия и созданы условия Аля развития лидерства учителей с целью улучшения образования в классе, школе и на уровне системы. Проекты мидерства учителей смогли оказать воздействие на практику внутри класса и школы. Результаты исследования показывают, что развитие лидерства учителей требует расширения профессиональной роли учителя и трансформацию школы в самообучающуюся организацию. Таким образом, успех реализации реформ в системе среднего образования зависит от наращивания потенциала внутри школы путем создания условии Аля развития лидерства и оказания подлержки учителям.

Ключевые слова: развитие килерства учителей, милерство школы, профессиональное обучение, реформа в школе, исследование в действии.

\section{Кіріспе}

2011 жылдан бері еліміздің орта білім беру саласында елеулі реформалар орын алуда. Аталмыш реформаларды мемлекетіміздің 2050 жылға дейін алдыңғы қатарлы 30 дамыған елдің қатарына қосылу мақсатымен байланыстыруға болады (OECD, 2014) [1]. Тұрақты экономикалық дамуды қамтамасыз ету, орта білім беру жүйесінің сапасын арттыру және мектептердегі әрбір оқушының сапалы білімге қол жеткізулерін қамтамасыз ету мақсатында, орта білім саласында бірнеше маңызды реформалар басталды. Бұл мақсаттарға жетудің басты тетігі ұстаздардың кәсібилігін арттыру болды (OECD, 2014). Мемлекеттің тікелей қолдауымен елімізде 52,000 астам ұстаздар мен мектеп әкімшілігі (2015 жылғы көрсеткіш) кәсіби біліктілікті арттыру бағдарламаларына қатысты (Wilson, 2017) [2]. Назарбаев зияткерлік мектептердің аясында Педагогикалық шеберлік орталықтары пайда болып, деңгейлік бағдарламалар енгізілді: бірінші деңгей - ұстаздар мен мектеп әкімшілігінің желілік қоғамдастықтар құрып, көшбасшылық етуге; екінші деңгей - ұстаздардың рефлексия жасау дағдыларын арттыруға; ал, үшінші деңгей - ұстаздардың сыныпты басқару әлеуетін арттыруға бағытталған. Дегенмен, басты мақсат ұстаздар мен мектеп әкімшілігі алған кәсіби білімді сыныптың, мектептің және білім беру жүйесін тұрақты дамыту мақсатында қолданысқа енгізіліп, реформаны жылдамдатуға қолдау көрсету еді (Wilson, 2017). Осы тұрғыда:

1. Ұстаздардың кәсібилігін арттыруда олардың жаңңа білімді құолданысқұа енгізіп, сынып пен мектеп ішінде өзгеріс енгізулері үшін, басқаша айтқ̧анда, сынып пен мектеп ішінен бастау алатын көшбасшылықты іске асыру үшін ұстаздарва құандай қолдау көрсетуіміз құажет? және 2) сол арқылы рефрормалардың сәтті іске асуын ққалай жылдамдата аламыз? - деген сияқты сұрақтарға жауап табу маңызды. Себебі, еліміздегі орта білім саласындағы реформалардың сәтті іске асуы мектеп ішіндегі көшбасшылық әлеуеттің дамуына тікелей тәуелді (OECD, 2014).

\section{Концептуалды негіздер}

Соңғы 30 жыл бойы орта білім беру саласын реформалауға қатысты жасалған зерттеулер, реформалардың сәтті іске асуы ұстаздардың кәсіби әрекеттеріне тікелей тәуелді екендігін алдыға тартады (Fullan, 1982, Schleicher, 2016) [3-4]. Алдыңғы қатарлы дамыған білім беру жүйелерінің тәжірибелеріне сүйенсек, аталмыш елдерде ұстаздардың көшбасшылық әлеуетін, олардың өздерінің кәсіби әрекеттеріне деген сенімдерін және кәсібилігін арттыруға баса назар аударатындығын көруге болады (Schleicher, 2012) [5]. Осы тұрғыда, келесі тараушаларда реформаларға ықпал ететін сыртқы факторлар, мектептің ішкі көшбасшылық әлеуетін арттыру және лауазымға тәуелсіз ұстаз көшбасшылығы дамыту мәселелері қарастырылады.

Реформаларва ықпал ететін сыртқы факторлар

XX ғасырдың 60 жылдарынан бері білім беру саласы мен мемлекеттің экономикалық дамуы өзара тығыз байланыста қарастырылып келеді (Schultz, 1961) [6]. Осы күнде де білім беру саласы қандай да болмасын мемлекеттің экономикалық дамуының басты тетіктерінің бірі болып есептеледі. Халықаралық зерттеулерге сүйенсек, “... білім беру саласындағы құндылықтар өз алдына бөлек қарастырылудан қалып, неолибералды экономикалық ойлаудың бір бөлігіне айналып кетті" (Rizvi \& Lingard, 2010:196) [7]. Аталмыш ұстаным, OECD (ЭЫДҰ) немесе UNESCO (ЮНЕСКО) сияқты 
халықаралық ұйымдар мен PISA және TIMSS сияқты білім сапасын бағалайтын жүйелердің пайда болуына әкеліп соқтырды. Бұл ұйымдар, әлемдік деңгейде білім саясаттарын жасап, білім беру жүйелерінің сапасын бағалау арқылы мемлекеттердің экономикалық тартымдылығын арттырып, оларды өзара салыстыруға мүмкіндік алды. Аталмыш ұйымдардың ұсыныстарын қабылдау немесе қабылдамау әр елдің өз еншісінде болғанымен (Wiseman, 2013) [8], олар жекелеген елдердің білім беру жүйелерінде орын алып жатқан реформаларға тікелей ықпал етуде (Grek, 2009; Niemann et al., 2017) [9-10]. Әсіресе, білім сапасын өлшеудің құралдары дұрыс жетілмеген елдердің білім беру саясатын анықтау жағынан бұл ұйымдардың тигізетін ықпалы аса жоғары болуы мүмкін (Rizvi \& Lingard, 2010; Ball, 2012) [7, 11]. Мысалы, сондай білім саясаттарының ішінде дамушы елдерге арнап жазылған PISA-D сияқты бастамалар да бар. Бұл сырттан келетін саясаттардың жекелеген мемлекет деңгейінде орталықтандырылған реформалардың артуына апарады. Жоғарыдан төменге түсірілетін реформалардың саны артқан сайын, оларды орындаумен байланысты талаптар арта береді, ал ол өз алдына мектеп ішіндегі мамандардың арасында өздерінің кәсіптеріне деген қызығушылықтары мен кәсіби маман ретіндегі рөлдерінің төмендеуіне әкеліп соқтыруы мүмкін (Elmore, 2004; Fullan, 2016) [12-13]. Дамыған елдерде бұл үдеріс 'перформативизм' немесе көзбояушылық мәдениеттің пайда болуына әкелді (Lyotard, 1984) [14]. Стефен Болл бұл үдерісті былай сипаттайды (Ball, 2003:216) [15]:

... сыйақы, жазалау жүйесі мен талаптар енгізіп, ұстаздарды өзара салыстыру мен бағалау арқылы олардың жұмысқа деген ынтасын арттыруға, басқаруға және өзгеріс енгізуге бағытталған мәдениет.

Аталмыш мәдениетте жұмыс жасайтын ұстаздар үшін “кәсіби еркіндік пен шығармашылық" артта қалып, “басқалардың алдында өзін жақсы көрсету” бірінші орынға шығады (Lunneblad \& Dance, 2014: 309) [16]. Ұстаздарының жетістіктері оқушыларының тестіден алған бағаларымен өлшенетін мектептерде, шығармашылық пен кәсібилік сияқты құндылықтар маңызды болудан қалады (Nicholl \& McLellan, 2008) [17]. Нәтижесінде, білім сапасын арттыру мен тұрақты экономикалық дамуды мақсат етіп басталған реформалар көп жағдайда көзбояушылықпен аяқталады
(Darling-Hammond, 2009) [18]. Осы тұрғыда, реформалардың сәтті іске асуы мектеп ішіндегі кәсіби әлеуетті артыруға және ұйым ретінде мектептің рөлін қайта қарауды талап етуі мүмкін.

Мектеп көшбасшылывы мен дамуы

Әлемдік зерттеулер окушылардың білім алуына және білім жүйесінің дамуына тікелей әсер ететін ең басты фактор, ол - ұстаздардың кәсіби әрекеттерінің сапасы екендігі белгілі (Darling-Hammond, 2000; OECD, 2009) [19-20]. Дегенмен, ұстаздардың кәсіби әрекеттері көп жағдайда мектептің ішкі жағдайымен тікелей байланысты. Яғни, мектеп ішіндегі жағдаят білім берудің дамуына немесе артта қалуына әсер етуі мүмкін (MacBeath \& Mortimer, 2001) [21]. Мектептері автономды ұйым ретінде қарастырылатын батыс елдерінде, 'мектептің тиімділігін арттыру' немесе 'мектепті дамыту' деген сияқты ұғымдар кең таралған (Hopkins, 2001) [22]. Нақтырақ айтқанда, зерттеушілер мектептің ішкі дамуын іске асыратын үш басты тәсілдерді анықтайды: біріншісі, тактикалық тәсіл - ұстаздардың назары оқушылардың білім көрсеткіштеріне қарай бағытталған; екіншісі, стратегиялық тәсіл - мектеп ұзақ уақытты даму мақсаттарын анықтап, ұстаздардың назары оқушылардың шынайы білім алуына бағытталған; үшіншісі, мектеп іміндегі кәсіби әлеуетті арттыруга бавытталван тәсіл - мектеп ішіндегі жүйе қайта қаралып, ұстаздардың назары өзара ынтымақтастық пен өзін өзі бағалауға бағытталған (Gray et al., 1999) [23]. МакБес пен Мортимордың айтуынша "мектеп дамуының басты көрсеткіші, ол - мектеп ішінде үздіксіз білім алуға жасалған жағдаят (MacBeath \& Mortimore, 2001:18). Яғни, мектептің дамуы, оның ішінде ұстаздардың кәсіби дамуына жасалған жағдаймен өлшенеді. Осы тұрғыда ұстаз кәсібилігі деген ұғымды дұрыс анықтап алу маңызды.

Зерттеулерге сүйенсек, кәсіби маман деген ұғымды көп жағдайда жоғарыдан келген талаптарды уақытында орындайтын немесе ұстаздардың лауазымдарының (кәсіби деңгейдің) жоғарылауымен байланыстырылады. Дегенмен, кәсібиліктің тағы бір түрі бар, ол - ұстаздың өзіндік моральдық құндылықтарының негізінде, күнделікті тәжірибеде сыныбындағы және мектебіндегі оқу мен оқыту үдерісін дамытуға бағытталған әрекеттері (Hoyle \& Wallace, 2009) [24]. Соңғысы, лауазымына қарамастан, ұстазды оқу мен оқыту үдерісіне жетекшілік ете алатын, өз бетімен кәсіби білімнің негізін қалай 
алатын тұлға ретінде қарастырады (Durrant \& Holden, 2005) [25]. Өзінің күнделікті тәжірибесі жөнінде терең ойлану мен үздіксіз білім алу арқылы ұстаздар төменнен төбеге қарай жүретін мектептің дамуына өз үлестерін қоса алады (Fullan, 2007). Осы тұрғыда, мектеп ішінде ұстаздардың кәсібилігі мен көшбасшылығының дамуына жағдай жасау маңызды болуы мүмкін.

Лауазымва тәуелсіз ұстаз көшбасшылывы

Ұстаз көшбасшылғы ұғымы өткен ғасырдың 80 жылдарынан бастап кең қолданысқа ие бола бастады. Сол кезеңде, жоғары оқу орындарындағы оқытушылар мен мектеп ұстаздары, АҚШ-та орын алып жатқан реформалардағы ұстаздардың рөлін арттыру және олардың тәжірибелерін ескеру керектігін алдыға тартты (Devaney, 1987) [27]. Қазіргі таңда, аталмыш ұғым мектептің ішкі әлеуетін арттырудың басты құралы ретінде қаралуда. Дамыған білім беру жүйелерінде ұстаздар білім беру саясаты жөнінде шешім қабылдауға және ол шешімдерге ықпал етуге құзыреттері бар. Сол арқылы, ұстаздардың өз кәсібіне деген қызығушылықтары артып, ұстаздық ету қоғамда жоғары бағаланатындығын көруге болады (Schleicher, 2015) [28]. Жалпы, дамыған білім беру жүйелерінде көшбасшылықты, бір жағынан, мектеп деңгейінде автономия беру арқылы, ал, екінші жағынан, мектептерге орталықтандырған қолдау көрсету арқылы дамытуда (Mourshed et al., 2010; Schleicher, 2012) [29]. Зерттеулер, ұстаз көшбасшылығының дамуына жүйелі түрде қолдау көрсету мен ұстаздардың мектептің дамуына атсалысуға мүмкіндік алуларының арқасында, ұстаздардың өздеріне және өздерінің істеп жатқан істеріне деген сенімдері артатындығын көрсетеді (Schleicher, 2015; Berry et al., 2016) [30].

Дегенмен, ұстаз көшбасшылығы деген ұғым әр елде әртүрлі мағынаға ие. АҚШ немесе Австралия мектептерінде ұстаз көшбасшылығы белгілі бір лауазымдармен байланыстырылады (Lieberman et al., 1988; Katzenmeyer \& Moller, 2009) [31-32]. Мысалы, ұстаз-ментор, ұстаз-коуч, әдістемелік бөлімдердің жетекшілері, мектеп әкімшілігі және т.б. Керісінше, Ұлыбританияда ұстаз көшбасшылығы дегеніміз әрбір ұстаздың оқу мен оқыту үдерісін дамытуға бағытталған әрекеттері деп қарастырылады (Durrant \& Holden, 2005; MacBeath et al., 2018) [33].

Осы зерттеудің аясында ұстаз көшбасшылығын лауазымы мен рөліне қарамастан әрбір ұстаздың білім беру жүйесін дамытуға қатысты құзыреті ретінде қарастырылады (Bangs \& Frost, 2016) [34]. Яғни, ұстаз сынып және мектеп ішінен кәсіби білім жасап, өзгеріс пен даму енгізе алатын кәсіби мамандар ретінде қарастырылады (Durrant \& Holden, 2005). Аталмыш ұстанымды Фрост (2011) лауазымzа тәуелсіз ұстаз көшбасшылыхы деп атайды (Frost, 2011) [35]. Көшбасшылық әрбір ұстаздың моральдық ұстанымдарына негізделеді. Нақтырақ айтатын болсақ, ұстаз өздерінің құндылыққтарын түсініп, өздерінің кәсіби мәселелерінің аясында даму бадыттарын анықтап, сыныбы, мектебі мен ортасын дамытуға бағытталған стратегиялық әрекеттер жасайды (Frost et al, 2000). Дегенмен, ұстаз көшбасшылығы өзінен өзі пайда болмайды, ол үшін арнайы стратегиялар мен мектеп ішінде жағдаят жасау қажет (Fullan, 2007).

Ұстаз көшбасшылывын мектеп ішінен даMblmy

1999 жылы британдық мектептерде ұстаз көшбасшылығын дамыту мақсатында Кембридж университеті Білім беру факультетінде ХартсКем (Хартфордшир және Кембридж) деген мектеп пен университет арасындағы кәсіби қоғамдастық құралды (https://www.hertscam.org. $\mathrm{uk} /$ ). Аталмыш ынтымақтастықтың аясында, ұстаз көшбасшылығын дамытуға бағытталған Ұстаз жетекшілігімен жүргізілетін дамьmу жұмысы (the Teacher-led development work strategy) атты стратегия пайда болады (Frost et al., 2000). Стратегия Халықаралық ұстаз көшбасшылығы бастамасының аясында әлемнің 17 елінде және 150 мектептерінде апробациядан өткен (Frost, 2011). Стратегияның аясында ұстаздар бір оку жылы бойы бірнеше қадамдардан тұратын бағдарламаны мектеп ішінде жүргізеді: өздерінің құндылықтарын анықтайды; кәсіби мәселелерін анықтайды; өздерінің мәселелерін басқа әріптестерімен талқылайды; іс-әрекет жоспарын құрады; бір оқу жылы бойы дамыту жобаға жетекшілік етеді; желілік қауымдастықта кәсіби білімнің негізін қалайды (Hill, 2014) [36].

Осы зерттеу жұмысының аясында, Ұстаз жетекшілігімен жүргізілетін дамыту жұмысы стратегиясының негізінде Қазақстанның төрт мектебінде "Кәсіби білім алу мен ынтымақтасуға бағытталған ұстаз көшбасшылығы” атты бағдарлама жүргізілді. Бағдарлама тоғыз айға созылып, алты мектеп ішіндегі топтық сессиялар, үш бетпе-бет кездесулер, екі мектепаралық кездесулер мен қорытынды конференция өткізілді. Сонымен қатар, Бағдарламаның ұстаздардың және мектептің тәжірибесіне тигізген ықпалы 
зерттелді. Зерттеу әдіснамасы мен құралдары туралы ақпарат келесі бөлімде түсіндіріледі.

\section{Зерттеу әдіснамасы мен құралдары}

Бұл бөлімде зерттеудің әдіснамасы мен деректерді жинау құралдары, жиналған ақпаратты талдау және зерттеу қатысушылары жөнінде ақпарат беріледі.

Зерттеу әдіснамасы

Аталмыш зерттеу жобасы сыни құатыспальы іс-дрекеттегі зерттеу дыіснамасына негізделген (Kemmis et al., 2014) [37]. Зерттеудің басты мақсаты ұстаз көшбасшылығын дамыту бағдарламасын енгізу және оның ықпалын бавалаува бағытталды. Ұстаздармен бірге әрекет ету арқылы білім жасау көзделді. Дегенмен, басты назар ұстаздардың емес, зерттеушінің өзінің әрекеттерін жүйелі түрде зерттеуге бағытталды. Зерттеу жүргізу барысында оған толыққанды қатысушы ретінде әр мектептен бір фасилитатордан мектеп өкілдері анықталып, олармен қарым-қатынас орнатылды. Мектеп өкілдері Бағдарламаны енгізуге жетекшілік етуге және жиналған зерттеу материалдарына кері байланыс беруге қатысты.

\section{Зерттеу құралдары мен талдау жолдары}

Бағдарламаны бақылау мен бағалау мақсатында Курт Левиннің іс-әрекеттік зерттеу спиральдары қолданылды (Lewin, 1946) [38]. Деректерді жинау құралдарының арасында (i) бетпе-бет сұхбаттар (ii) қатыспалы бақылаулар (iii) Бағдарлама материалдарын талдау (iv) зерттеу күнделігі. Деректерді талдауда тақырыптық және ашық кодтау тәсілдері қолданылды. Бұл, бір жағынан, жиналған ақпаратты алдын ала анықталған тақырыптарға сәйкес топтастыруға, ал, екінші жағынан, жаңа тақырыптардың туындауына ашық болуға мүмкіндік берді (Strauss \& Corbin, 1990) [39].

\section{Зерттеуге құатысушылар}

Бағдарлама қатысушыларын таңдауда өз қалауымен қатысу қағидасы негізге алынды. Сол себепті, зерттеу қатысушыларын анықтауда кездейсоқ бағытталған таңдау (random purposeful sampling) тәсілі қолданылды (Miles \& Huberman, 1994) [40]. Соның нәтижесінде, қатысушылар әртүрлі пән ұстаздары мен мектеп әкімшілігінің өкілдерінен тұрды. Бағдарламаға қатысушылардың жалпы саны 31 адамнан тұрды.

\section{Этикалық мәселелерді ескеру}

Аталмыш зерттеу жобасы Кембридж университеті Білім беру факультетінде іске асқан докторлық диссертацияның аясында жүргізілді (Kanayeva, 2019) [41]. Сол себепті, аталмыш зерт- теу Британдық білім беру саласындағы зерттеу ассоциациясының (British Educational Research Association) және Кембридж университеті Білім беру факультетінің этикалық талаптарына сай ұйымдастырылды. Ондағы ең басты талаптар, зерттеу қатысушыларына, олардың ойларын ашық білдіруге, олардың құқықтарына, білімге, демократиялық құндылықтарға құрмет білдіру. Сонымен қатар, зерттеу қатысушыларының анонимділігін қамтамасыз ету және жиналған деректердің қауіпсіз жерде сақтау арқылы зерттеудің сапасы қамтамасыз етілді (BERA, 2011) [42]. Аталмыш зерттеуге қатысқан барлық мектептер мен қатысушыларға бүркенші аттар берілген.

\section{Зерттеудің барысы}

Ic-әрекеттегі зерттеудің дәстүрлі зерттеу әдістерінен басты өзгешелігі - зерттеушінің рөлі. Сырттан бақылап, деректерді жинап, оларды талдаудың негізінде білім жасаудың орнына, зерттеуші зерттеудің бір бөлігіне айналады, зерттеуге қатысушылармен қарым-қатынас орнатып, тәжірибеге немесе қоғамға өзгеріс алып келуге және аталмыш әрекеттердің негізінде пайда болған білімді теориялауға тырысады. Яғни, өзгеріс әкелу теориясын тек зерттеудің соңына қарай толыққанды жүйелей алады (Wilson, 2009) [43]. Тоғыз айға созылған "Кәсіби білім алу мен ынтымақтасуға бағытталған ұстаз көшбасшылығы" атты бағдарламаның аясында (бұдан әрі - Бағдарлама) ауқымды деректер жиналды. Бағдарламаны енгізу арқылы мектеп ішінде ұстаз көшбасшылығын дамыту бірнеше кезеңдерден тұратындығы белгілі болды. Олар: көшбасшылық етуге жавдай жасау; көшбасшылықтың багытын анықтау; көшбасшылықыты іске асыру және жүріп өткен жолға рефлексия жасау немесе ой жүгірту (1-кесте).

Көшбасшылық етуге жавдай жасау

Зерттеудің бірінші кезеңінде мектеп ішінде үздіксіз кәсіби даму мен көшбасшылықты дамытуға қажетті жағдай жасау жұмыстары жүргізілді. Зерттеудің бастапқы кезеңінде мектеп ішінде жүйелі түрде іске асатын көшбасшылық пен кәсіби даму Бағдарламасын енгізу мектептер үшін жаңашыл тәжірибе болғандығы белгілі болды. Соның ішінде мұндай бастамаларды мектептерге енгізу үшін ең алдымен уақыт, арнайь жиналатын орын мен мектеп басшыльвының ұдайы қолдауы маңызды екендігі белгілі болды. Дегенмен, бұлар көп жағдайда мектептерде жеткіліксіз болды. Әсіресе, жалпы орта білім беретін мектептерде уақыт мен орынның 
тапшылығы ерекше сезілді. Бағдарламаға қатысушылардың басты бөлігі дүйсенбі мен сенбі арасында екі ауысымда сабақ беріп, жұмыс күндері таңғы 8.00-ден кешкі 19.00-ге дейін созылды. Оқушы санының көп болуына байланысты мектепте ұстаздарға бас қосып, кәсіби дамуды іске асыруға кабинеттер жетіспеді, ал кейбір мектептерде ұстаздар бөлмесі болма- ды. Сонымен қатар, ұстаздардың кәсіби дамуы мен көшбасшылығына қолдау көрсетуде мектеп директорларының рөлдері шектеулі болды. Көп жағдайда, ұстаздардың кәсіби дамуы мектептен тыс, арнайы ұйымдарда іске асатын курстар ретінде қарастырылғандықтан, мектеп әкімшілігінің рөлі сол курстарға қатысатын ұстаздарды таңдап, жіберумен шектелді:

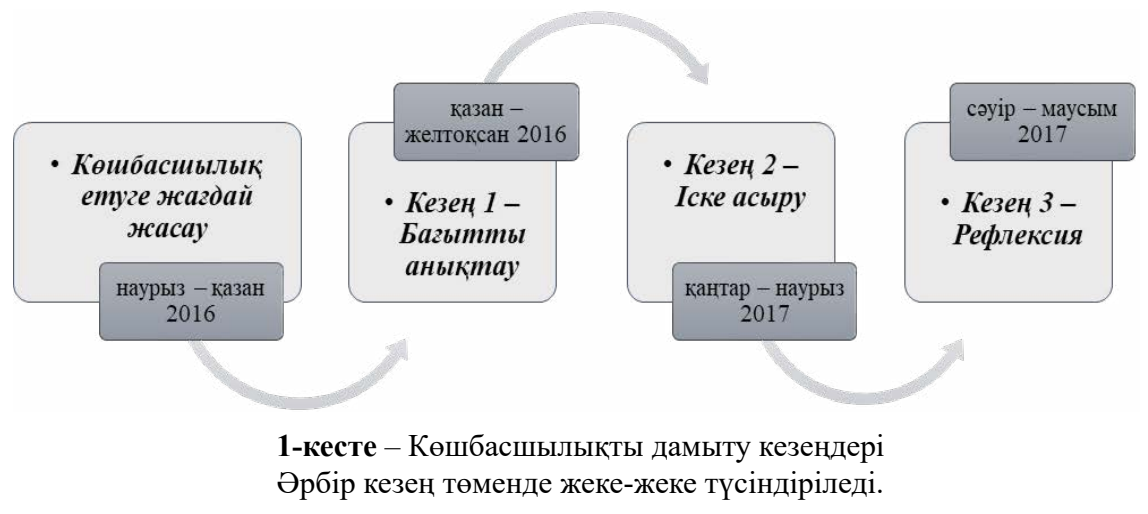

Реформалардың бір бөлігі ретінде Педагогикалық шеберлік орталывы және басқ̧а біліктілікті арттыру бавдарламалары бар [...]. Сол бавдарламаларва сай келетін ұстаздарды біз таңдап, жібереміз [...] (Мектеп директоры, Бірлік мектебі).

Сол себепті, ұстаз көшбасшылығын мектеп ішінен дамытуға бағытталған Бағдарламаны енгізу үшін біраз дайындық жұмыстарын жүргізу маңызды болды. Оның ішінде, мектеп басшыларымен кездесіп, Бағдарламаға өз қалауларымен қатысқысы келетін мектептерді анықтау; ол мектептерде Бағдарламаға қатысу үшін ұстаздарға уақыт пен орын бөлу; Бағдарламаны зерттеушімен бірге іске асыратын фасилитаторларды (Бағдарлама жетекшілерін) мектеп әкімшілігінің арасынан анықтау; және Бағдарлама қатысушыларымен қарымқатынас орнату кірді. Әлеуметтік зерттеудің бір түрі болғандықтан, іс-әрекеттегі зерттеудің маңызды бөлігінің бірі зерттеуге қатысушылармен өзара сенім мен құрметке негізделген қарым-қатынас орната білу маңызды болды (Herr \& Anderson, 2005) [44]. Осы мақсатта, мектеп басшылары, фасилиаторлар мен ұстаздардың алдында Бағдарламаның мақсаты егжей-тегжейлі түсіндіріліп, іс-әрекет жоспары өзара талқылау арқылы анықталды. Бағдарламаға өз еркімен қатысуға төрт мектептен 31 ұстаз бен мектеп әкімшілігінің өкілдері өз келісімдерін берді.

\section{1-кезецу: К Көшбасшылықтың бавытын} анықтау

Бағдарлама конструктивистік оку теориясына, яғни кәсіби білімді ұстаздар өз бетімен және басқа әріптестерімен ынтымақтасу арқылы жасай алады деген түсінікке негізделген (Dewey, 1916) [45]. Бағдарламаның басты мақсаттарының бірі, ұстаздарға кәсіби құндылықтарын және күнделікті тәжірибелерінде оларды мазалайтын бір кәсіби мәселені анықтауға қолдау көрсету болды. Аталмыш әрекеттер топтық сессиялар кезінде фасилитатордың арнайы құралдар енгізуі арқылы іске асты. Кәсіби мәселені анықтап алғаннан кейін, әрбір ұстаз іс-әрекет жоспарын құрып, сыныптағы немесе мектептегі тәжірибеге өзгеріс енгізу мақсатында бір оқу жылы бойы дамыту жобаға жетекшілік етті. Оку жылының соңында дамыту жобаларының аясында кәсіби білімнің негізін қалауға мүмкіндік алды. Дегенмен, барлық қатысушылар бірдей конструктивистік оқу теориясы негізінде өз бетімен ізденіп, білім құрауға дайын болмады. Көп жағдайда, фасилитатордан келесі әрекеті жөнінде нақты нұсқаулықтар беруді сұрап отырды:

[...] Совет заманында бізге "мынаны бірінші, мынаны екінші істе”, - деген нақты нұсқаулар берілетін. Біз сол нұсқауларды орындап үйреніп қุалганбыз. Сол себепті, бізге келесі кездесуге дейін не icmen келу керек екендігін айта аласыз ба? (Күлзия, Талап мектебі). 
Сол себепті, Бағдарлама барысында ұстаздардың өз бетімен көшбасшылық бағытты анықтап, өз бетімен жобаға жетекшілік ету мақсатында фасилитацияның сарынын ауыстырып отыру маңызды болды. Мысалы, Бағдарлама басында нақты нұсқау беруден басталып, кейін ұстаздар өз бағыттарын нақтылап алғаннан кейін оларға өз еркімен әрекет етуге жол ашу маңызды болды. Ұстаздарға көшбасшылық жобаларының бағытын анықтап, оған жауапкершілік алуға түрткі болған басты фактор - мектепаралық кездесулер кезінде, басқа әріптестерден кері байланыс алу болды. Яғни, мектепаралық кездесулер мен әріптестер арасындағы ынтымақтастық, ұстаз көшбасшылығының дамуына ықпал ететін басты факторлардың бірі екендігі белгілі болды:

Бізге әртүрлі дамыту жобалары жайында тыңдап, өзара талқылаулар жасау өте пайдаль болды. Осындай мүмкіндіктер жиі берілсе екен деген өтініш (топтық рефлексия, 1-ші мектепаралық кездесу, 14.01.2017)

\section{2-кезең: Көшбасшылықты іске асыру}

Бағдарлама қатысушылары дамыту жобаларының бағыты мен іс-әрекет жоспарларын анықтағаннан кейін оларға әртүрлі қолдау түрі қажет болды. Біреулері өзгеріс стратегиясын мен құралдарды ойластырып жатса, енді біреулері оларды тәжірибеге енгізіп үлгерді. Әсіресе, тәжрибесі аз, ұстаздық жолды енді бастаған ұстаздарға қолдау көрсету маңызды болды. Мысалы, Замира мектепте ұстаз болып алғашқы жыл жұмыс істеп жатқандықтан, өзгеріс енгізуді неден бастау керек екендігін білмеді. Сол себепті, Замираға стратегия дамытуда фасилитатордың көмегі қажет болды. Сол арқылы, ол стратегияны енгізіп, окушылардан кері байланыс алып, келесі әрекетін жоспарлауға мүмкіндік алды:

Замира алтыншы сынып оқушыларының биология сабавына қызызушшылықтарын арттыруды алдына мақусат етіп қойды. Жобасын неден бастарын әлі нақтты білмейді. Ован сабақта құолданатын құралдарының тиімділігін түсіну мақсатында, алдымен оқушылардың пікірін есту маңызды болуы мүмкін екендігін ұсындым. Ол сауалнама құрастырып, окушыларва таратуды жоспарлап отыр (зерттеу күнделігі, 23.01.2017, 67 бет).

Дегенмен, Бағдарламаның бірінші кезеңімен салыстырғанда қатысушыларда өздерінің дамыту жобалары жөнінде тереңірек түсінік қалыптасып, жобалары арқылы неге ықпал ету керек екендігі жөнінде нақты түсініктері болды. Олардың көбісінің мақсаттары оқушылардың білім алуын жетілдірумен байланысты бол- ды. Мысалы, Райгүл дамыту жобасының соңында тәжірибеге төмендегідей ықпал етуді жоспарлады:

Дамыту жоба соңын тамамдаванда окушыларым диалог кезінде өз ойларын ашық айтудан жасқанбайтын болады. Олардың ойларын басққалар сынга алванда, олар сынды көтере алатын болады. Өздерінің ойларының дұрыс екендігіне сенімді болван кезде, оны дәлелдей алатын болады. Окушыларым терең ойланува үйренеді (Райгүл, жазбаша рефлексия, Бірлік мектебі, 16.02.2017).

Бағдарламаның ең маңызды кезеңі көшбасшылық жобаларды іске асырумен байланысты болғанмен, ұстаздардың назарын тәжірибені дамытуға бағыттап отыру оңайға соқпады. Ең басты кедергі, сырттан келетін тексерістермен байланысты болды. Жергілікті Білім басқармасынан келетін тексерісті күткен мектептердің назары құжаттарының дұрыс болуына ауа бастады. Ұстаздардың кәсіби дамуы мектеп аттестациясының бір бөлігі болуына қарамастан (GoK, № 1270, 2007) [46], қатысушылардың көбісі бұл іс-шараның техникалық түрде іске асатынын алдыға тартты. Мысалы, Адина бұдан бұрын аттестацияға тапсырған жобасы мен Бағдарлама аясында жүргізіп жүрген көшбасшылық жобасының арасындағы айырмашылық жөнінде төмендегідей пікір білдірді:

\footnotetext{
Шызармашылық жоба жүргізгенде ештеңчені түсінем немесе өзгертем деп талпындан жоқпын. Қажетті құжаттарды жинап, дарынды және артта қалушы окушылармен жұмыс іспегенім жөнінде құжаттарымның болуын құамтамасыз етуім керек болды. Алайда, дамыту жобасы мүлдем басқаша. Бұнда окушыларымның білім алуын дамыту үшін әрекет ету керек. Басқа әріптестерім де істеп жатқанжұмысымыз жөнінде көбірек ойланатын болдық дейді. Бұл бізге қызыққ болгандықтан, өз кқалауымызбен құатысыли жүрміз. Өз қалауыңмен жобава жетекшілік ету мүлдем басқаша екен (Адина, Бірлік мектебі, 22.02.17).
}

\section{3-кезең: Рефлексия}

Бағдарламаның бірінші кезеңімен салыстырғанда, соңғы кезеңде ұстаздардың көшбасылық ұғымы жөнінде көзқарастарының өзгергендігін байқауға болды. Бағдарлама басында ұстаздар көшбасшылықты лауазыммен немесе мектеп әкімшілігімен байланыстырса, дамыту жобаларды іске асыру арқылы ұстаздар көшбасшылықты әрекет ретінде көре бастағандығы байқалды (топтық сессия хаттамасы, Ынтымақ мектебі, 26.04.2017). Әсіресе, ұстаздар ‘жоғарыдан” келген нұсқауларсыз өзде- 
рінің күнделікті әрекеттері арқылы тәжірибеге өзгеріс енгізе алатындығын алдыға тартты:

Ocы дамыту жобава жетекшілік етпестен бұрын, мен көшбасшы деген үнемі елдің алдында жүретін адам деп ойлайтынмын [...] бірақ көшбасшы деген өзінің әрекеті арқылы өзгеріс енгізіп, басқ̧алармен ынтымақтаса алатын, оларва ықпал ете алатын адам екендігіне көзім жетті (жазбаша рефлексия, Алуа, Талап мектебі).

Ұстаздардың дамыту жобалары тәжірибеге әртүрлі деңгейде ықпал етті. Жобалардың негізгі бөлігі сыныптағы тәжірибені дамытуға бағытталды. Дегенмен, кейбіреулері мектеп пен қоғам арасындағы ынтымақтастықты арттыра алды. Мектептегі қазақ тілінің қолданысын арттыру мақсатында Алуа оқушыларының қауымдастық құруға қолдау көрсетті. Қауымдастық мүшелері бір оқу жылы бойы қазақ тілінде оқушылар журналын шығарып, өздері жазған өлеңдері мен шығармаларын сол жерде бөлісті. Оқу жылының соңында қауымдастық мүшелері жергілікті жетім балалар үйіне және қариялар үйіне арнап салтанатты кеш ұйымдастырды:

Концерт мектептің үлкен залында орын алды. Зал қуонақтарва лық толь. Окушылар өздерінің қауылмдастызын таныстырды. Өздерінің шызармаларын оқыды. Театрлық шывармаларды ққазақ тілінде қойып, келген қонақтарды өнерлерімен тәнті етті. Іс-шара келген құонақтардың тіл мен әдебиетке деген қызывушылықтарын арттыргандывы сөзсіз (қатыспалы бақылау, Талап мектебі, 19.04.17).

Бағдарлама соңында ұстаздар өздерінің жүріп өткен жолдары жөнінде рефлексиялық әңгіме жазды. Олардың әңгімелерінен ұстаздардың бойында әрекет етуге деген сенімдері артқандығы байқалды. Әңгіме жазу тәсілі арқылы ұстаздар әлеуметтік әрекеттердің ішіндегі өздерінің рөлдерін анықтай алған сыңайлы (Clandinin \& Connelly, 2000) [47]. Төмендегі рефлексиядан ұстаздардың сыртқы ықпалдан арылып, өз беттерімен әрекет етуге деген ынталарының артқандығын байқауға болады (Bandura, 1997) [48]:

Өз мақсатыма жету үшін әрекетімді жоспарлап, жолда кездесуі мүмкін кедергілерді анықтап, жобама қзатысты ддебиет көздерін іздеп үйрендім [...]. Дамыту жобава жетекшілік ету арқылы тек әрекет еткендер вана өздерінің және басққалардың тәжірибесіне ықпал ете алатындывын, басқ̧аларва ыққпал ету арқылы өзгеріс әкеліп, кәсіби маман ретінде өсе алатындызын ұzындым (Алуа, Талап мектебі, рефлексивті әңгіме).

\section{Зерттеу нәтижелерін талқылау}

Лауазымға тәуелсіз ұстаз көшбасшылығын дамытуға бағытталған Бағдарламаны бір оқу жылы бойы Қазақстанның төрт мектептеріне енгізіп, оның ықпалын зерттеу арқылы: (1) сынып пен мектеп ішінен бастау алатын көшбасшылықтың іске асыру үшін ұстаздарға қандай қолдау көрсетуіміз қажет екендігін және, (2) сол арқылы, орта білім саласындағы реформаларды жылдамдатуға қандай жағдай жасай алатындығымызды түсінуге тырыстық. Жалпы, зерттеу нәтижелері ұстаздардың кәсібилігі мен көшбасшылығының өзара тығыз ұғымдар екендігін және оларды дамыту үшін мектептің ұйым ретінде рөлін қайта қайрауымыз қажет екендігін көрсетті.

Ұстаз кәсібилігі мен көшбасшыльвьы

Халықаралық зерттеу ұстаздардың кәсіби тұлғасы білім беру жүйесі мен мектеп ішінде қалыптасатындығын алдыға тартады (Day, 2002; Wilkins et al., 2012; Lightfoot \& Frost, 2014) [4951]. Әлеуметтік ғылымдар саласына 'структурация' ұғымын енгізген Энтони Гидденстің (Giddens, 1984) [52] ойынша адамның тұлға болып қалыптасуына орта үлкен ықпал етеді, бірақ адам да өзінің агенттілігі, яғни әрекеті арқылы ортаның өзгеруіне ықпал ете алады. Осы зерттеудің аясында жүйе мен мектеп ішіндегі жағдайға қоса, ұстаздардың кәсіби тұлғалары көбіне сырттан келген талаптарды орындаумен байланысты болды. Жоғарыдан келіп жатқан реформалардың ауқымды (мысалы, үштілділік саясаты, жаңартылған білім беру бағдарламасы, жаңа бағалай жүйесі және т.б.) болуына байланысты ұстаздардың рөлі сол саясаттарды түсініп, тәжірибелеріне дұрыс енгізумен ғана шектелетіндігі белгілі болды. Бұндай жағдайда ұстаздардың кәсіби рөлі тек сырттан келген реформаларды іске асырушы, яғни 'техник' ретінде қарастырылуына апаруы мүмкін. Ал, бұл өз алдына ұстаздардың бойында аталмыш реформаларға деген скептицизмнің артуына апаратындығы мәлім (Bantwini \& Letseka, 2016) [53]. Осы тұрғыда, Хойл (Hoyle, 1975) [54] ұстаздардың кәсіби тұлғаларын кеңейту керек екендігін алдыға тартады. Кәсібилік деген ұғымды жоғарыдан келген тапсырмаларды орындаумен немесе аттестациядан өтумен емес ұстаздардың моральдық құндылықтарын негізге ала отырып, күнделікті әрекеттері арқылы сынып пен мектептің ішіндегі оқу мен оқытудың және жалпы ұйымның дамуына ықпал етуі деп қарастыру маңызды (Hoyle \& Wallace, 2009; 
Bangs \& Frost, 2016). Ұстаз кәсібінің түп тамыры оқу мен оқытудан тұратындықтан, оқу мен оқытуды ісіне көшбасшылық ету үшін ұстаздарға лауазымның қажеті жоқ. Ұстаздарға қажеттісі үздіксіз кәсіби даму арқылы өздерінің және басқалардың тәжірибелеріне ықпал ете білу, сол арқылы кәсіби білімнің негізін қалау (Durrant \& Holden, 2006; Frost, 2011). Дегенмен, постсоветтік елдерде ұстаздардың бойындағы кәсіби белсендік пен көшбасшылықты ояту үшін арнайы стратегиялар мен қолдау қажет болуы мүмкін (Teleshaliyev, 2015) [55]. Бұл өз алдына ұстаздардың кәсіби білім алуын және мектеп ішінде арнайы жағдай жасауды талап етуі мүмкін.

Мектеп ішінен кәсіби білім алу мен көшбасшылықтың дамуына жавдай жасау

Ұстаз көшбасшылығы орын алу үшін мектеп ішінде үздіксіз кәсіби дамуды қамтамасыз ету маңызды болып табылады. Ол үшін мектеп 'өзін-өзі оқытатын ұйымға' айналуы қажет (Senge, 1990) [56]. Біріншіден, ұстаздық ету ұдайы ізденіс пен дамуды талап етеді: өзінің кәсіби мәселесін анықтап, оны түсіну және шешу арқылы ұстаз рефлективті маманға айнала алады (Argyris \& Schön, 1996) [57]. Ол үшін ұстаздарға ұдайы кері байланыс беру маңызды, себебі бұл ұстаздардың істеп жатқан істері жөнінде саналылықтары мен сыртқы ықпалдардың алдында табандылықтарын арттыра алады (Schön, 1987) [58]. Сонымен қатар, ұстаздар басқа әріптестермен тәжірибе алмасуға мүмкіндік алу керек. Аталмыш зерттеудің аясында, мектепаралық кездесулер кезінде әріптестердің берген кері байланысы ұстаздардың көшбасшылық бастамаларына қатысты жауапкершіліктері мен қызығушылықтарын арттыруы мүмкін екендігін көрсетті. Бұл дегеніміз, ұстаздардың бойында көшбасшылық тұлғаның қалыптасуы уақыт пен мектеп ішінен көрсетілетін жүйелі қолдауды қажет етеді деген сөз (Allen, 2016; Sinha \& Hanuscin, 2017; Boylan, 2018) [59-61]. Екіншіден, ұстаз көшбасшылығының дамуына мектеп ішіндегі жағдай, яғни уақыт, орын және мектеп әкімшілігінің қолдауы қажет (Frost \& Durrant, 2002; Harris \& Muijs, 2004) [62-63]. Күнделікті сабақ беру мен мектептің әкімшілік жұмыстарының арасында ұстаздардың кәсіби дамуына, біздің жағдайда басқа әріптестермен бас қосып кәсіби талқылаулар жүргізуге, сол арқылы оқу мен оқытуға өзгеріс енгізуге уақыт пен орын бөлу маңызды. Аталмыш зерттеудің аясында ұстаздар мен мектеп әкімшілігінің негізгі уақыты сабақ беру мен жоғарыдан кел- ген “қағаз жұмысқа" кететіндігі белгілі болды. Сонымен қатар, халықаралық зерттеулерге сүйенсек ұстаз көшбасшылығының дамуына мектеп директорының ықпалы жоғары (Crowther, 2002; Louws et al., 2017) [64-65]. Мысалы, мектеп директоры ұстаздардың кәсіби дамуына жетекшілік ету, мектеп ішіне өзгеріс енгізуде көшбасшылықпен бөлісу және ұстаздардың жетістіктерін мадақтау арқылы ұстаз көшбасшылығының дамуына ықпал ете алады. Аталмыш қолдау арқылы, мектеп директоры мектеп ішінде оқу мен оқытуды дамытуға бағытталған кәсіби мәдениет қалыптастыра алады (Frost, 2012; Hargreaves \& Fullan, 2012) [66-67]. Аталмыш зерттеудің аясында мектеп директорының рөліне қоса, ұстаз көшбасшылығының дамуына жергілікті білім басқармасының ықпалы да жоғары екендігі белгілі болды. Осы тұрғыда, мектеп ішінде ұстаз көшбасшылығы мен кәсіби дамуды қамтамасыз ету мақсатында жергілікті білім басқармалардың рөлдерін қайта қарау маңызды көрінеді. Яғни, жергілікті білім басқармалары мектептерден “қағаздың" түзу болуын талап етуден гөрі мектепаралық қауымдастықтың дамуына, мектеп ішінде ұстаздардың кәсіби дамуы мен көшбасшылығына қолдау көрсетілуіне назар аудару арқылы реформаларды жылдамдатуға ықпал ете алар еді. Фулланның (Fullan, 2005) [68] зерттеулеріне сүйенсек, реформалардың сәтті іске асуы жергілікті білім басқармалардың қолдауына тікелей тәуелді: “олардың басты рөлі мектеп ішіндегі үздіксіз оқу мен оқытудың маңызды екендігін түсіну және соған қолдау көрсету" (67 бет). Түбінде оқу мен оқытуға қолдау көрсетудің орнына, жалаң талап ету мен жазалау мәдениеті, мектеп ішіндегі реформалардың көзбояушылықпен аяқталуына апаруы мүмкін (Ball, 2003; Lunneblad \& Dance, 2014).

\section{Қорытынды}

Қорытындылай келе, іс-әрекеттегі зерттеуге негізделген аталмыш зерттеу жобасы тоғыз айға созылды. Зерттеу барысында Қазақстанның төрт мектебіне лауазымға тәуелсіз ұстаз көшбасшылығы бағдарламасы енгізілді. Зерттеу қорытындылары мектеп ішіндегі ұстаз кәсібилігі мен көшбасшылығының дамуына арнайы қолдау көрсетілудің маңызды екендігін көрсетті. Мектеп ішінен ұстаз көшбасшылығының дамуына қолдау көрсету мектептің тұтас ұйым ретінде дамуына және білім беру жүйесінде орын алып жатқан реформаларды жылдамдатуға 
оң әсерін тигізетіндігі белгілі болды. Сонымен қатар, аталмыш зерттеу аясында халықаралық тестілеу жүйелері мен талаптарына сай болуға ұмтылудан бұрын мектептеріміздің ішкі әлеуетін арттырудың маңызды екендігін көрсетті. Осы тұрғыда, орта білім беру саласын реформалауға итермелейтін сыртқы талаптар мен мектептеріміздің ішіндегі кәсіби және көшбасшылық әлеуеттің арасындағы қарымқатынас келешек зерттеулерге арқау бола алады.

\section{Әдебиеттер}

1 Organisation for Economic Co-operation and Development (OECD). Secondary Education in Kazakhstan: Reviews of National Policies for Education. 2014.

2 Wilson, E. Alternative paths to upgrading existing teacher qualifications: the Kazakhstan- based Centre of Excellence Teacher Education Programme in Hartley, M \& Ruby, A. (Eds) (In Press) Higher Education Reform and Development: The case of Kazakhstan, Cambridge University Press. 2017.

3 Fullan, M. The meaning of educational change. - Toronto: OISE press. 1982.

4 Schleicher, A. Teaching Excellence through Professional Learning and Policy Reform: Lessons from Around the World // International Summit on the Teaching Profession.- Paris: OECD Publishing. 2016.

5 Schleicher, A. Preparing Teachers and Developing School Leaders for the 21 st Century: Lessons from around the World. OECD Publishing. 2012.

6 Schultz, T. Investment in Human Capital // The American Economic Review. - 1961.- №51(1). - Р.1-17 // Эл.pecypc: http:// www.jstor.org/stable/1818907 Дата доступа: January 6, 2021

7 Rizvi, F., Lingard, B. Globalising education policy. - London: Routledge, 2010.

8 Wiseman, A.W. Policy responses to PISA in comparative perspective // Heinz-Dieter, M. and Benavot, A. (Eds.) PISA, Power and Policy: the emergence of global educational governance, 303-322. - Oxford: Symposium, 2013.

9 Grek, S. Governing by numbers: the PISA ‘effect' in Europe // Journal of Education Policy. - 2009.- №24(1), 23-37. DOI: https://doi.org/10.1080/02680930802412669

10 Niemann, D., Martens, K., Teltemann, J. PISA and its consequences: Shaping education policies through international comparisons // European Journal of Education, 2017. - Vol. 52, 175-183. DOI: https://doi.org/10.1111/ejed.12220

11 Ball, S.J. Global education inc.: New policy networks and the neo-liberal imaginary. -London: Routledge, 2012.

12 Elmore, R.F. School Reform from the Inside Out. - Cambridge, MA: Harvard Education Press, 2004.

13 Fullan, M. The new meaning of educational change (5th ed.). - London: Routledge, 2016.

14 Lyotard, J. F. The postmodern condition: A report on knowledge, 1984. - (Vol. 10). U of Minnesota Press, 1984.

15 Ball, S. J. The teacher's soul and the terrors of performativity // Journal of education policy, 2003. - 18(2), 215-228. DOI: https://doi.org/10.1080/0268093022000043065

16 Lunneblad, J., Dance, L. J. Performativity pressures at urban high schools in Sweden and the USA// Ethnography and Education. - 2014. - №9(3). - P. 298-312. DOI: https://doi.org/10.1080/17457823.2014.907746

17 Nicholl, B., \& McLellan, R.'We're all in this game whether we like it or not to get a number of As to Cs., Design and technology teachers' struggles to implement creativity and performativity policies // British Educational Research Journal. - 2008. - № 34(5). - P. 585-600. DOI: https://doi.org/10.1080/01411920802223875

18 Darling-Hammond, L. Teaching the change wars: the professionalism hypothesis // Hargreaves, A., Fullan, M. (Eds.) Change wars. - Bloomington: Solution tree. - 2009.- Pp. 45-68

19 Darling-Hammond, L. Teacher quality and student achievement // Education policy analysis archives, 2000. -№ 8(1). -P. 1-44. DOI: https://doi.org/10.14507/epaa.v8n1.2000

20 Organisation for Economic Co-operation and Development (OECD). Education at a Glance: 2009: OECD indicators. OECD Publishing, 2009.

21 MacBeath, J. and Mortimer, P. Improving school effectiveness. - Buckingham: Open University Press, 2001.

22 Hopkins, D. School improvement for real. Psychology Press, 2001

23 Gray J, Hopkins D, Reynolds D, Wilcox B, Farrell S., Jesson, D. (1999). Improving Schools: Performance and Potential, Buckingham: Open University Press.

24 Hoyle, E., \& Wallace, M. Leadership for professional practice // Gewirtz, S., Mahony, P., Hextall, I., Cribb A. (2009). (Eds.) Changing teacher professionalism: international trends, challenges and ways forward. - London: Taylor \& Francis. 2009.

25 Durrant, J., Holden, G. Teachers leading change: Doing research for school improvement. - London: Paul Chapman Educational Publishing, 2005

26 Fullan, M. The new meaning of educational change. - New York: Teachers College Press, 2007.

27 Devaney, K. The lead teacher: Ways to begin. Carnegie Forum on Education and the Economy. 1987.

28 Schleicher, A. Schools for 21st-Century Learners: Strong Leaders, Confident Teachers, Innovative Approaches // International Summit on the Teaching Profession. - Paris: OECD Publishing, 2015.

29 Mourshed, M., Chijioke, C., Barber, M. How the world's most improved school systems keep getting better. - London: McKinsey, 2010 
30 Berry, B., Zeichner, N., Evans, R. Teacher leadership: a reinvented teaching profession // Evers, J. and Kneyber, R. (Eds.) Flip the system: changing education from the ground up. - London: Routledge, 2016. - P. 209-225

31 Lieberman, A., Saxl, E.R., Miles, M.B. Teacher Leadership: Ideology and Practice. In Lieberman, A. (Ed.) Building a professional culture in schools. - New York: Teachers College Press, 1988. - P. 148-166.

32 Katzenmeyer, M., Moller, G. Awakening the sleeping giant: Helping teachers develop as leaders. - Thousand Oaks CA: Corwin Press, 2009.

33 MacBeath J., Dempster, N., Frost, D., Johnson, G., Swaffield, S. Strengthening the connections between leadership and learning: challenges to policy, school and classroom practice. - London: Routledge, 2018.

34 Bangs, J., Frost, D. Non-positional teacher leadership: distributed leadership and self-efficacy // Evers, J. and Kneyber, R. (Eds.) Flip the system: changing education from the ground up. - London: Routledge, 2016. - P. 91-107,

35 Frost, D. Supporting teacher leadership in 15 countries: The International Teacher Leadership project, Phase 1 - A report. Cambridge: Leadership for Learning, 2011.

36 Hill, V. The HertsCam TLDW programme in Frost, D. (Ed.) Transforming education through teacher leadership // Transforming education through teacher leadership. - Cambridge: University of Cambridge, 2014. - P. $72-83$.

37 Kemmis, S., McTaggart, R., Nixon, R. The action research planner: doing critical participatory action research. - London: Springer, 2014.

38 Lewin, K. Action research and minority problems // Journal of Social Issues. - 1946. - № 2(4). - P.34-46. URL: http://www. fionawangstudio.com/ddcontent/Instructions/action_research/readings/Lewin_1 946_action\%20research\%20and $\% 20 \mathrm{minority} \% 20$ problems.pdf

39 Strauss, A.L., Corbin, J. (1990). Basics of qualitative research, Newbury Park: Sage.

40 Miles, M. B., Huberman, A. M. Qualitative data analysis: An expanded sourcebook. - London: Sage, 1994.

41 Kanayeva, G. Facilitating Teacher Leadership in Kazakhstan, unpublished PhD thesis.- Cambridge: University of Cambridge, 2019.

42 British Educational Research Association (BERA) // Ethical Guidelines for Educational Research, 2011. www.bera.ac.uk.

43 Wilson, E. Action Research // Wilson, E. (Ed.) School-based research: a guide for education students, London: Sage. 2009. - P. 189-202.

44 Herr, K. and Anderson G.L. (2005). The Action Research Dissertation: A Guide for Students and Faculty. Thousand Oaks CA: Sage.

45 Dewey, J. (1916). Introduction to essays in experimental logic. In J. A. Boydston (Ed.) The middle works (1899-1924), Vol. 10, 320-369. Carbondale and Edwardsville: Southern Illinois University Press.

46 Постановление Правительства Республики Казахстан от 24 декабря 2007 года N 1270 “Об утверждении Правил государственной аттестации организаций образования". - Астана, 2007.

47 Clandinin, D. J., Connelly, F. M. Narrative inquiry: Experience and story in qualitative research. Jossey-Bass San Francisco, CA. 2000 .

48 Bandura, A. Self-efficacy the exercise of control. - New York: W.H. Freeman, 1997.

49 Day, C. School reform and transitions in teacher professionalism and identity // International Journal of Educational Research, 2002. - №37.- P.677-692. DOI: https://doi.org/10.1016/S0883-0355(03)00065-X

50 Wilkins, C., Busher, H., Kakos, M., Mohamed, C., Smith, J. Crossing borders: new teachers co-constructing professional identity in performative times. Professional Development In Education. - 2012. - \#38(1). P. 65-77. DOI: https://doi.org/10.1080/19 415257.2011.587883

51 Lightfoot, S., Frost, D. The professional identity of early years educators in England: implications for a transformative approach to continuing professional development. Professional development in education, 2015. - №41(2). - P. 401-418. DOI: https:// doi.org/10.1080/19415257.2014.989256

52 Giddens, A. The constitution of society: outline of the theory of structuration. Cambridge: Polity press, 1984.

53 Bantwini, B. D., Letseka, M. South African teachers caught between nation building nd global demands: Is there a way out/ forward? Educational Studies, 2016. - 52(4), 329-345. DOI: https://doi.org/10.1080/00131946.2016.1190366

54 Hoyle, E. Professionality, professionalism and control in teaching. In V. Houghton et al. (Eds). Management in Education: The Management of Organisations and Individuals. London, Ward Lock Educational in association with Open University Press, 1975.

55 Teleshaliyev, N. Teachers with a Capital 'T': Exploring the professionalism of experienced teachers in Kyrgyzstan. Thesis submitted for the degree of Doctor of Philosophy (unpublished), Faculty of Education, University of Cambridge, 2015.

56 Senge, P. The fifth discipline: The art and science of the learning organization. New York: Currency Doubleday, 1990.

57 Argyris, C., Schön, D. A. Organizational Learning II: Theory and Method. Reading MA: Addison Wesley. 1996.

58 Schön, D. A. Educating the reflective practitioner. - San Francisco: Jossey-Bass. 1987.

59 Allen, D. The resourceful facilitator: Teacher leaders constructing identities as facilitators of teacher peer groups// Teachers and Teaching, 2016. - 22(1). - P.70-83. DOI: https://doi.org/10.1080/13540602.2015.1023029

60 Sinha, S., Hanuscin, D. L. Development of teacher leadership identity: A multiple case study // Teaching and Teacher Education, 2017. - №63. -P. 356-371. DOI: https://doi.org/10.1016/j.tate.2017.01.004

61 Boylan, M. Enabling adaptive system leadership: Teachers leading professional development // Educational management administration \& leadership, 46(1), 86-106. DOI: https://doi.org/10.1177\%2F1741143216628531

62 Frost, D., Durrant, J. Teachers as leaders: Exploring the impact of teacher-led development work // School leadership \& management, 2002. -№ 22(2). -P. 143-161. DOI: https://doi.org/10.1080/1363243022000007728 
63 Harris, A., Muijs, D. Improving schools through teacher leadership. - McGraw-Hill Education (UK). 2004.

64 Crowther, F. Big change question: Is the role of the principal in creating school improvement over-rated? // Journal of Educational Change, 2002. -№ 3(2). -P. 167-173. DOI: https://doi.org/10.1023/A:1016572429951

65 Louws, M. L., Meirink, J. A., van Veen, K., van Driel, J. H. Exploring the relation between teachers' perceptions of workplace conditions and their professional learning goals // Professional Development in Education, 2017. -№ 43(5). -P. 770-788. DOI: https://doi.org/10.1080/19415257.2016.1251486

66 Frost, D. From professional development to system change: teacher leadership and innovation // Professional development in education, 2012. -№ 38(2). - P. 205-227. DOI: https://doi.org/10.1080/19415257.2012.657861

67 Hargreaves, A., Fullan, M. Professional capital: transforming teaching in every school. - London: Routledge. 2012.

68 Fullan, M. Leadership \& sustainability: System thinkers in action. Corwin Press. 2005.

69 Frost, D., Durrant, J., Head, M., Holden, G. Teacher-led school improvement. - London: Routledge and Falmer. 2000.

\section{References}

Allen, D. (2016). The resourceful facilitator: Teacher leaders constructing identities as facilitators of teacher peer groups. Teachers and Teaching, 22(1), 70-83. DOI: https://doi.org/10.1080/13540602.2015.1023029

Argyris, C., \& Schön, D. A. (1996). Organizational Learning II: Theory and Method. Reading MA: Addison Wesley.

Ball, S. J. (2003). The teacher's soul and the terrors of performativity. Journal of education policy, 18(2), 215-228. DOI: https://doi.org/10.1080/0268093022000043065

Ball, S.J. (2012). Global education inc.: New policy networks and the neo-liberal imaginary. London: Routledge.

Bandura, A. (1997). Self-efficacy the exercise of control. New York: W.H. Freeman.

Bangs, J. \& Frost, D. (2016). Non-positional teacher leadership: distributed leadership and self- efficacy. In Evers, J. and Kneyber, R. (Eds.) Flip the system: changing education from the ground up, 91-107, London: Routledge.

Bantwini, B. D. \& Letseka, M. (2016). South African teachers caught between nation building and global demands: Is there a way out/forward? Educational Studies, 52(4), 329-345. DOI: https://doi.org/10.1080/00131946.2016.1190366

Berry, B., Zeichner, N. \& Evans, R. (2016). Teacher leadership: a reinvented teaching profession in Evers, J. and Kneyber, R. (Eds.) Flip the system: changing education from the ground up, 209-225, London: Routledge.

Boylan, M. (2018). Enabling adaptive system leadership: Teachers leading professional development. Educational management administration \& leadership, 46(1), 86-106. DOI: https://doi.org/10.1177\%2F1741143216628531

British Educational Research Association (BERA) (2011). Ethical Guidelines for Educational Research, www.bera.ac.uk.

Clandinin, D. J., \& Connelly, F. M. (2000). Narrative inquiry: Experience and story in qualitative research. Jossey-Bass San Francisco, CA.

Crowther, F. (2002). Big change question: Is the role of the principal in creating school improvement over-rated?. Journal of Educational Change, 3(2), 167-173. DOI: https://doi.org/10.1023/A:1016572429951

Darling-Hammond, L. (2000). Teacher quality and student achievement. Education policy analysis archives, 8(1),1-44. DOI: https://doi.org/10.14507/epaa.v8n1.2000

Darling-Hammond, L. (2009). Teaching the change wars: the professionalism hypothesis. In Hargreaves, A. \& Fullan, M. (Eds.) Change wars. (pp. 45-68). Bloomington: Solution tree.

Day, C. (2002). School reform and transitions in teacher professionalism and identity. International Journal of Educational Research, 37, 677-692. DOI: https://doi.org/10.1016/S0883- 0355(03)00065-X

Devaney, K. (1987). The lead teacher: Ways to begin. Carnegie Forum on Education and the Economy.

Dewey, J. (1916). Introduction to essays in experimental logic. In J. A. Boydston (Ed.) The middle works (1899-1924), Vol. 10, 320-369. Carbondale and Edwardsville: Southern Illinois University Press.

Durrant, J. \& Holden, G. (2005). Teachers leading change: Doing research for school improvement, London: Paul Chapman Educational Publishing.

Elmore, R.F. (2004). School Reform from the Inside Out. Cambridge, MA: Harvard Education Press.

Frost, D. (2011). Supporting teacher leadership in 15 countries: The International Teacher Leadership project, Phase $1-A$ report, Cambridge: Leadership for Learning.

Frost, D. (2012). From professional development to system change: teacher leadership and innovation. Professional development in education, 38(2), 205-227. DOI: https://doi.org/10.1080/19415257.2012.657861

Frost, D., \& Durrant, J. (2002). Teachers as leaders: Exploring the impact of teacher-led development work. School leadership \& management, 22(2), 143-161. DOI: https://doi.org/10.1080/1363243022000007728

Frost, D., Durrant, J., Head, M. \& Holden, G. (2000). Teacher-led school improvement. London: Routledge and Falmer.

Fullan, M. (1982). The meaning of educational change. Toronto: OISE press.

Fullan, M. (2005). Leadership \& sustainability: System thinkers in action. Corwin Press.

Fullan, M. (2007) The new meaning of educational change. New York: Teachers College Press.

Fullan, M. (2016). The new meaning of educational change ( $5^{\text {th }}$ ed.). London: Routledge.

Giddens, A. (1984). The constitution of society: outline of the theory of structuration. Cambridge: Polity press.

GoK (2007). Resolution of the Government of the Republic of Kazakhstan dated December 24, 2007 N 1270 "On approval of the Rules for state certification of educational organizations"] [Postanovleniye pravitel'stva Respubliki Kazakhstan ot 24 dekabrya 2007 goda N 1270 "Ob utverzhdenii Pravil gosudarstvennoy attestatsii organizatsiy obrazovaniya"] (In Russian) 
Gray J, Hopkins D, Reynolds D, Wilcox B, Farrell S \& Jesson, D (1999). Improving Schools: Performance and Potential, Buckingham: Open University Press.

Grek, S. (2009). Governing by numbers: the PISA 'effect' in Europe. Journal of Education Policy, 24(1), 23-37. DOI: https:// doi.org/10.1080/02680930802412669

Hargreaves, A. \& Fullan, M. (2012). Professional capital: transforming teaching in every school, London: Routledge.

Harris, A., \& Muijs, D. (2004). Improving schools through teacher leadership. McGraw-Hill Education (UK).

Herr, K. and Anderson G.L. (2005). The Action Research Dissertation: A Guide for Students and Faculty. Thousand Oaks CA: Sage.

Hill, V. (2014). The HertsCam TLDW programme in Frost, D. (Ed.) Transforming education through teacher leadership, Transforming education through teacher leadership, 72- 83, Cambridge: University of Cambridge.

Hopkins, D. (2001). School improvement for real. Psychology Press.

Hoyle, E. (1975). Professionality, professionalism and control in teaching. In V. Houghton et al. (Eds). Management in Education: The Management of Organisations and Individuals. London, Ward Lock Educational in association with Open University Press.

Hoyle, E., \& Wallace, M. (2009). Leadership for professional practice. In Gewirtz, S., Mahony, P., Hextall, I., Cribb A. (2009). (Eds.) Changing teacher professionalism: international trends, challenges and ways forward. London: Taylor \& Francis.

Kanayeva, G. (2019) Facilitating Teacher Leadership in Kazakhstan, unpublished PhD thesis. Cambridge: University of Cambridge.

Katzenmeyer, M., \& Moller, G. (2009). Awakening the sleeping giant: Helping teachers develop as leaders. Thousand Oaks CA: Corwin Press.

Kemmis, S., McTaggart, R. \& Nixon, R. (2014). The action research planner: doing critical participatory action research. London: Springer.

Lewin, K. (1946). Action research and minority problems. Journal of Social Issues, 2(4), 34-46. URL: http://www.fionawangstudio.com/ddcontent/Instructions/action_research/readings/Lewin_1 946_action\%20research\%20and\%20minority\%20problems. pdf

Lieberman, A., Saxl, E.R. \& Miles, M.B. (1988). Teacher Leadership: Ideology and Practice. In Lieberman, A. (Ed.) Building a professional culture in schools, 148-166. New York: Teachers College Press.

Lightfoot, S., \& Frost, D. (2015). The professional identity of early years educators in England: implications for a transformative approach to continuing professional development. Professional development in education, 41(2), 401-418. DOI: https://doi.or $\mathrm{g} / 10.1080 / 19415257.2014 .989256$

Louws, M. L., Meirink, J. A., van Veen, K., \& van Driel, J. H. (2017). Exploring the relation between teachers' perceptions of workplace conditions and their professional learning goals. Professional Development in Education, 43(5), 770-788. DOI: https:// doi.org/10.1080/19415257.2016.1251486

Lunneblad, J. \& Dance, L. J. (2014). Performativity pressures at urban high schools in Sweden and the USA. Ethnography and Education, 9(3), 298-312. DOI: https://doi.org/10.1080/17457823.2014.907746

Lyotard, J. F. (1984). The postmodern condition: A report on knowledge (Vol. 10). U of Minnesota Press.

MacBeath J., Dempster, N., Frost, D., Johnson, G. and Swaffield, S. (2018) Strengthening the connections between leadership and learning: challenges to policy, school and classroom practice, London: Routledge.

MacBeath, J. and Mortimer, P. (2001). Improvingschool effectiveness, Buckingham:

Miles, M. B., \& Huberman, A. M. (1994). Qualitative data analysis: An expanded sourcebook, London: Sage.

Mourshed, M., Chijioke, C., \& Barber, M. (2010). How the world's most improved school systems keep getting better. London: McKinsey.

Nicholl, B., \& McLellan, R. (2008). 'We're all in this game whether we like it or not to get a number of As to Cs., Design and technology teachers' struggles to implement creativity and performativity policies. British Educational Research Journal, 34(5), 585- 600. DOI: https://doi.org/10.1080/01411920802223875

Niemann, D., Martens, K. \& Teltemann, J. (2017). PISA and its consequences: Shaping education policies through international comparisons. European Journal of Education, Vol. 52, 175- 183. DOI: https://doi.org/10.1111/ejed.12220

Open University Press.

Organisation for Economic Co-operation and Development (OECD) (2009). Education at a Glance: 2009. OECD indicators. OECD Publishing.

Organisation for Economic Co-operation and Development (OECD) (2014). Secondary Education in Kazakhstan, Reviews of National Policies for Education.

Rizvi, F. \& Lingard, B. (2010). Globalising education policy. London: Routledge.

Schleicher, A. (2012). Preparing Teachers and Developing School Leaders for the 21st Century: Lessons from around the World. OECD Publishing.

Schleicher, A. (2015). Schools for 21st-Century Learners: Strong Leaders, Confident Teachers, Innovative Approaches, International Summit on the Teaching Profession, Paris: OECD Publishing.

Schleicher, A. (2016). Teaching Excellence through Professional Learning and Policy Reform: Lessons from Around the World, International Summit on the Teaching Profession, Paris: OECD Publishing.

Schön, D. A. (1987). Educating the reflective practitioner. San Francisco: Jossey-Bass.

Schultz, T. (1961). Investment in Human Capital. The American Economic Review, 51(1), 1-17. Retrieved January 6, 2021, from http://www.jstor.org/stable/1818907 
Senge, P. (1990). The fifth discipline: The art and science of the learning organization. New York: Currency Doubleday.

Sinha, S., \& Hanuscin, D. L. (2017). Development of teacher leadership identity: A multiple case study. Teaching and Teacher Education, 63, 356-371. DOI: https://doi.org/10.1016/j.tate.2017.01.004

Strauss, A.L. \& Corbin, J. (1990). Basics of qualitative research, Newbury Park: Sage.

Teleshaliyev, N. (2015). Teachers with a Capital 'T': Exploring the professionalism of experienced teachers in Kyrgyzstan. Thesis submitted for the degree of Doctor of Philosophy (unpublished), Faculty of Education, University of Cambridge.

Wilkins, C., Busher, H., Kakos, M., Mohamed, C., \& Smith, J. (2012). Crossing borders: new teachers co-constructing professional identity in performative times. Professional Development In Education, 38(1), 65-77. DOI: https://doi.org/10.1080/194152 57.2011 .587883

Wilson, E. (2009). Action Research. In Wilson, E. (Ed.) School-based research: a guide for education students, 189-202. London: Sage.

Wilson, E. (2017). Alternative paths to upgrading existing teacher qualifications: the Kazakhstan-based Centre of Excellence Teacher Education Programme in Hartley, M \& Ruby, A. (Eds) (In Press) Higher Education Reform and Development: The case of Kazakhstan, Cambridge University Press.

Wiseman, A.W. (2013). Policy responses to PISA in comparative perspective. In Heinz-Dieter, M. and Benavot, A. (Eds.) PISA, Power and Policy: the emergence of global educational governance, 303-322. Oxford: Symposium. 